Perescu, I. (2021). Theatrical games in education. Problems of Education and Teaching in the Era of Digital Society. European Scientific e-Journal, 2 (8), 78-87. Hlučín-Bobrovníky: “Anisiia Tomanek” OSVČ.

Perescu, I. (2021). Jocurile teatrale în educație. Problems of Education and Teaching in the Era of Digital Society. European Scientific e-Journal, 2 (8), 78-87. Hlučín-Bobrovníky: “Anisiia Tomanek" OSVČ. (în engleză)

DOI: $10.47451 /$ ped2021-01-001

The paper will be published in Crossref, ICI Copernicus, Academic Resource Index ResearchBib, J-Gate, ISI International Scientific Indexing, Zenodo, OpenAIRE, BASE, LORY, LUASA, ADL, eLibrary, and WebArchive databases.

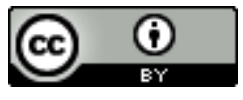

Ioana Perescu, Doctoral Student, University of Theatre and Cinematic Art "I.L. Caragiale". Bucharest, Romania.

\title{
Theatrical games in education
}

Abstract: This article represents the conclusions of the observations following the organization of a series of theatre workshops for approximately four years. The premise from which the evaluation of the participating subjects - children, teenagers, adults from 6 to 38 years - was that any game of theatre, improvisation game can be adapted according to the age of individuals so that they can develop skills such as memory, attention etc. The game proposals in this article have led to the conclusion that theatre games are important in the evolution of an individual. This article describes various ways in which theatrical games, theatrical improvisation games, contribute to an individual's education of his or her age. Whether it's a child, a teenager or an adult, the game develops a series of useful lifelong skills. This paper is the basis of further research on the impact of theatrical games on individuals' life.

Keywords: game, improvisation, education, artistic education, teacher, teaching principles, skills, theatre workshops.

Ioana Perescu, Doctorand, Universitatea de Artă Teatrală şi Cinematografică „I.L. Caragiale”. Bucureşti, România.

\section{Jocurile teatrale în educaţie}

Abstract: Acest articol reprezintă concluziile observațiilor în urma organizării unor serii de ateliere de teatru de-a lungul unei perioade de aproximativ patru ani. Premisa de la care s-a pornit în evaluarea subiecților participanți - copii, adolescenți, adulți cu vârsta cuprinsă între 6 şi 38 de ani - a fost aceea conform căreia orice joc de teatru, de improvizație poate fi adaptat în funcție de vârsta indivizilor în aşa fel încât aceştia să îşi poată dezvolta aptitudini precum memoria, atenția etc. Propunerile de exerciții din acest articol au condus către concluzia conform căreia jocurile teatrale sunt importante în evoluția educației unui individ. În acest articol sunt descrise diverse modalități prin intermediul cărora jocurile teatrale, jocurile de improvizație teatrală pot contribui la educația unui individ, indiferent de vârsta sa. Fie că este vorba despre un copil, un adolescent sau un adult, jocul dezvoltă o serie de aptitudini utile pe tot parcursul vieții. Această lucrare reprezintă baza unei cercetări viitoare despre impactul jocurilor teatrale în viaţa unui individ. 
Cuvinte cheie: joc, improvizație, educație, educație artistică, profesor, principii didactice, aptitudini, ateliere de teatru.

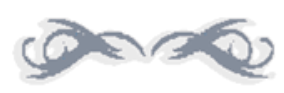

\section{Introduction}

Throughout an individual's life, the game plays an essential role in his psychological, educational, emotional development, etc. From the age of six months to six to seven years, a period coinciding with the start of school, the main activity by which a child develops his affective, sensory, etc. abilities are the game. With the passage of time, the place of this activity is taken by the concern to learn and work. However, in the conduct of learning and work processes, the game plays an important role. So, e.g., a pre-teen will find it much easier to assimilate some information if he also appeals to the game.

In his work Education and Child Development, Ph.D. Lecturer Mihai Diaconu recalls the conviction of A.N. Lentiev (Russian psychologist) that "the game is a specific mechanism of assimilation of the socio-human environment" (Diaconu, 2007). Therefore, through game children aim, for example, to imitate the actions of adults. Even if they relate differently to the environment and the concepts discovered, using the game, children manage to achieve the goals they have set themselves. So, if a child plans to play the role of a cook who cooks a soup, he will, despite not having the real ingredients; for him, it will be enough to use leaves instead of meat, twigs as kitchen utensils, etc. In the case of the game, the conclusion is not important, but how its stages are carried out. "The game world is therefore anticipation of the world of serious concerns." (Chateau, 2018)

Following studies, Jean Piaget (Swiss psychologist) established that there is a close link between the degree of development of thinking and the progress of the game. Starting from this conviction, the famous psychologist divides the games into the following categories: games exercise, games - symbolic, and games with rules. The premiums are specific to children between zero and two years of age; they "assume a repetition of activity for the purpose of adaptation" (Psibologia Varstelor Dezvoltării, 2020), e.g., a baby who presses several times on a toy - rattles. As regards the second category, they are characteristic of the period between two and six years and are 'based on the transformation of the real by assimilating it to the needs of "me" - "him" (Psibologia V arstelor Dezvoltării, 2020); e.g., a pencil can become, if necessary, a sword. Rules games are passed from one child to another, from one group of children to another. (e.g. catch, catchup in the dark, etc.)

As it was mentioned at the beginning of the paper, the game also has an educational role ... as a specific teaching activity performs multiple functions: fun, creativity according to age, finally - modelling and training of children's personality" (Dominteanu, 2019). Through the game, children are more attracted to the themes presented in classes or optional workshops. Teachers can therefore use games to motivate students in the educational process.

In support of the above ideas, I have chosen to refer further to some speaking exercises that I worked on in a diction workshop with some first graders. Diction can seem a technical field, slightly boring, especially for small children who find no motivation to repeat the same speech exercise several times. Therefore, I believe that turning vocal training into a game is the 
best solution for achieving your goals - clearer speech, correcting speech defects, etc. I will refer further to three categories of exercises: breathing, facial muscle training, and correction of rotacism.

In the case of breathing exercises, we proposed the following games: keeping a flake as much in the air as possible by a team of children (everyone has to blow in such a way that the flake lands as late as possible on the floor) and the straw race (each participant receives a straw and a piece of paper; a route is established, and the race is won by the one who reaches the finish line the fastest by blowing in the paper with the help of the straw).

Concerning the second category of exercises, those of myo-gymnastics, I opted for the mirror scowling/jolly (sit face to face, two participants propose in turn frowning and cheerful pictures; each must imitate his colleague) and the crazy candy (the children go on a boat trip and, unfortunately, shipwreck on a desert island where they find some candy that subsequently turns out to be crazy; each has a candy glued to the apex of the tongue that pushes into the left cheek, then straight, which causes the tongue to try to touch the nose, etc.)

To correct rotacism we chose the car race (in teams of two - one being the driver, the other the engine, the children competed with each other) and interviewing with an alien (each participant played the role of the alien who came to visit Earth and answered the questions asked by his colleagues). Only one sound was used for both the engine and the alien's mode of communication: Brrr. It is known that frequent repetition of this Brrr is one of the basic methods in correcting this utterance defect. Using these tricks to children it was much easier for them to complete the exercises, but also to understand their purpose.

So, the game does not mean play, the game involves following rules in order to have a beneficial result, the game is a way that any teacher can call on to arouse the students' curiosity about the subject taught.

The teacher is not - and should not try to be - a creator. He is a gardener who knows how to grow "germs" (Chateau, 2018). So, a teacher must pay attention to each of his students, to his needs in such a way that it can be useful to him and to the whole group of which he is part. Taking into account the teaching principles, the teacher meets the needs of the participants in his courses. And in the case of artistic education, the coordinator of a theatre workshop, for example, can be guided by the same rules. In addition, respecting them will help the student to acquire other means of thinking, verbal expression, etc.

Therefore, the seven teaching principles that can also be applied in theatrical pedagogy are as follows:

- principle of intuition or unity between sensory and rational (use of senses in learning process);

- the principle of linking the theory of practice (the learning process is easier if the theoretical part is accompanied by practical examples);

- the principle of conscious and active acquisition of knowledge (the student is helped not to acquire his information mechanically);

- the principle of the systematization and continuity of knowledge (the teacher has the obligation to make a clear structure of the information he wishes to transmit); 
- the principle of accessibility of knowledge or respect for age specificities (information must be transmitted in such a way that it is easy for the receivers to understand it);

- principle of individualization and differentiation of learning (the teacher must always be attentive to how the student relates to the information received);

- the principle of thorough acquisition of knowledge (seeks the student to succeed in acquiring and using the information received).

My proposal to exemplify how these principles can be applied in the case of artistic education is to conduct a theatre workshop with atypical (blind) students from the sixth grade. I believe that the first step to be taken is to know the theoretical data on the characterization of the age of the participants; in this case, preadolescence.

Psychology specialists have set some clear criteria for characterizing students according to their state of school age. Thus, three main intervals of evolution (7-11 years were chosen: low schooling, 12-15 years: preadolescence, 16-18 years: adolescence), which were analysed from the perspective of physical and mental development (interests, cognitive and affective processes, relationships with the elderly) but also educational implications.

During this period the puberty child considers himself an adult and struggles to gain a higher status than those around him. His attitude is a consequence of the appearance of a strong sense of inferiority caused by the physical changes he goes through (e.g., hairiness in boys, breast augmentation in girls, etc.), changes that are often harmonious.

The child in pre-adolescence is impulsive, is critical, and his acceptance within groups of elderly people is a very important goal for him. In his paper entitled Education and Development of the Child, Ph.D. Lecturer Mihai Diaconu refers to puberty as ... "the age of irresistible attraction to group life" (Diaconu, 2007). Perhaps that is why any conflict that arises between preteens is very strong, and membership groups frequently change their composition.

As a result of the affective inconsistency that characterizes preadolescents, between 12 and 15 years of age, when the feeling of love is born, relationships with the opposite sex are fickle.

In terms of affectivity, psychologists have determined that a puber can go through less pleasant states (depression, anxiety, etc.) It may also exhibit behaviour that is not beneficial to him or others (e.g., drug use). An important role in defining the behaviour path of the preadolescent is the relationship between teachers and his parents. Using their pedagogical and communication skills, they can support the child so as to acquire positive, pro-social behaviour. One method that can result in this is to encourage participation in various age-specific activities (theatre workshops, painting, robotics, dance, etc.).

Cognitively, preadolescence is equivalent to the development of abstract thinking, logical memory and creative imagination.

So, here are a series of theatrical exercises that I would propose to this target group. For sensory development - tactile, olfactory, auditory, and taste, I would opt for the following games: recognition of different textures of certain foods (pasta, rice, sugar, coarse salt, fine salt, etc.), identifying colleagues according to their palms, listening to noises from the outside/inside of the classroom, establishing a product according to its smell (coffee, tea, etc.) and guessing edible goods according to their taste (chocolate, bread, apple, etc.). 
In the case of the second educational principle in the list, that of linking the theory of practice I would propose diction exercises: how a particular phoneme is pronounced and the vocal training for its consolidation.

As regards the principle of conscious and active appropriation of knowledge, the theatrical art teacher must pay attention to the level of understanding of an exercise and resume his explanation for each puzzled participant. This is true no matter how simple a game may seem.

The teacher must also have a clear structure of acting classes, so that the exercises are not proposed chaotically, at random. For example, in the first phase, several group exercises can be chosen to help participants work together, not to think about their own fears - the family portrait (group members must paint a portrait of a family of aliens, monkeys, singing instruments, etc.), popcorn (all participants turn into a microwaved popcorn bag), etc.

The principle of accessibility of knowledge or respect for age specificities is very important for a theatrical teacher because allows him to modify the exercises according to the participants. For example, the game typewriter is better suited to sixth graders - a dialogue without a letter. In the case of atypical children, exercises involving movement should be adapted to their needs.

The teacher must pay attention to all the participants in the workshop so that he can observe details such as the lightness with which one of them tells stories, sings, moves, etc. Thus, communication between teacher and child will always be effective.

Using the last principle in the list - the principle of thorough appropriation of knowledge the theatre workshop coordinator gives participants clear data on the purpose of an exercise so that its objectives are achieved. For example, children know from the very beginning, in the case of a circle-based memory game, that they need to discover ways to help them memorize as many words as possible spoken by their peers.

Knowledge and application of teaching principles in artistic education give the teacher the chance to be a better teacher. Even if he will not always be able to follow the plan designed at home, taking into account these suggestions, he will be able to improvise in favour of all the workshop participants, but also his own.

In order to get over all these bottlenecks quickly and find out as soon as possible the beauty of our job, the young man is invited to discover the easiest and at the same time the most efficient way. And this is the game (Darie, 2015).

And in the case of participants in a theatre workshop, participants who do not belong to the category of those who aspire to the status of the actor or those who already practice in the field of theatre/cinematography are about bottlenecks that need to be overcome, means of expression to be developed, etc. Therefore, play is important for both children and adults.

Theatre in education involves the development of a game scheme so that the individual can develop his creativity, spontaneity, imagination, etc. Because in the case of adults the game is more difficult to accept, I find it interesting and the approach to developing specific skills in art education as far as they are concerned.

Proposal for work - adult theatre workshop.

\section{Developing a sense of observation}


Observation definition: "A method intended to reveal a certain number of natural facts, based on which it will be possible to formulate a hypothesis which will be subject to experimental verification" (Sillamy, 1998).

Games proposal:

a) listening to noises from outside the work class (after this stage there is a discussion with all workshop participants about what they heard);

b) observing and retaining as many details as possible about colleagues while walking five Brownian minutes (after the end of the movement all participants talk about what they observed).

\section{Attention development}

Attention definition: "The concentration of the spirit on something. Being careful is, in a way, shutting yourself down from the outside world to focus on what interests you (...)" (Sillamy, 1998).

Games proposal:

a) observation of an object (after the expiry of the time allowed for this activity all participants submit their observations);

b) samurai (participants form a circle, use three pre-established movements to represent attack, defense and collaboration; these movements are accompanied by the following sounds: Ha, $\mathrm{He}$, Hi; one participant attacks - Ha, the attacked one defends himself - He, and the one on the right and the one on the left of the attacked one collaborates - Hi)

\section{Development of imagination}

Imagination definition: "The ability to represent our absent objects and combine images (...)" (Sillamy, 1998).

Games proposal:

a) In the metro station (using actions, creating relationships between the chosen characters, participants must build the given space);

b) Story by title (the trainer chooses a title, and participants collaborate and build a story).

\section{Developing empathy}

Empathy definition: "Resonance, effective communication with the fellow (...)" (Sillamy, 1998).

Games proposal:

a) It tells as if it were telling someone else (each participant chooses a story and recounts it as if told by another person they know very well - friend, boss, colleague, etc.);

b) Yes, and... (one of the participants proposes an action, for example, Let's go to the sea. Then another participant goes on to say: yes, and let's go in my car. The exercise ends when all participants have made a proposal for action. It is important that all actions are logical, related to each other.).

\section{Developing intuition}

Intuition definition: "Immediate and irrational understanding of the real (...)" (Sillamy, 1998). 
Games proposal:

a) What if...? (one of the participants leaves the workroom, the trainer chooses one person from among the other participants, the one who has left the room enters and asks them various questions that start with What if... so that at the end they can guess the person chosen; examples of questions: What if it were a colour? What if it was an animal? What if there was an emotion? etc.);

b) What's the age? (one participant chooses an age other than the one he has, goes through the workspace according to the choice made, and the other participants have to guess what age it is).

\section{Conflict development}

Conflict Definition: "Fighting trends, interests; in which an individual is subjected to opposing vector forces and almost equal powers. (...)" (Sillamy, 1998).

Games proposal:

a) leave/do not go (two of the participants must build a dialogue using only the proposed lines);

b) conflict object (choose an object that causes a conflict between two participants; the two must build a dialog in which the conflict occurs, but also resolve it at the end of the game).

\section{Conclusion}

Developing skills like those listed above means an added freedom in the way any individual acts, regardless of the profession they practice.

Thus, as coordinator of numerous theatre workshops for both children, adolescents, and adults, I have noticed positive changes due to improvisational games on how participants act and react. Therefore, I believe that it is never too early or too late to attend a workshop based on theatrical improvisation games. This article is a first step in conducting in-depth research on the impact of the game on the existence of an individual.

\section{References:}

Briceag, S. (2017). Psibologia vîrstelor: Curs universitar. Bălţi: Universitatea de Stat "Alecu Russo" din Bălți. (in Romanian)

Chateau, J. (2018). The Child and the Game. Bucharest: Didactic and Pedagogical Publishing House.

Darie, B. (2015). Actor's Art Course Improvisation. Bucharest: UNATC Press.

Diaconu, M. (2007). Education and Child Development. Bucharest: ASE Publishing House. (in Romanian)

Dominteanu, T. (2019). JOCUL ŞI ROLUL LUI ÎN DEZVOLTAREA COPILULUI. Vol. 1. Retrieved May 25, 2020, from www.marathon.ase.ro (in Romanian)

Improv Games. Retrieved May 24, 2020, from http://improvencyclopedia.org/games

Mandea, N. et al. (Eds.). (2018). Caietele Pedagogiei Teatrale. Vol. 1, Iss. 2 (2). București: UNATC Press. (in Romanian)

Popa, C. (2017). Notions of education psychology and class management. Bucharest: UNATC Press. 
Psihologia Varstelor Dezvoltării. Retrieved May 26, 2020, from https://www.academia.edu/13077918/Psihologia Varstelor_Dezvoltării (in Romanian) Sillamy, N. (1998). Dicționar de Psihologie. Bucureşti: Univers Enciclopedic. (in Romanian) Spolin, V. (2008). Improvisation for the theatre. Bucharest: UNATC Press. 